УДК 7.038.6+141.78](4)"197/200"(045)

ORCID ID: https://orcid.org/0000-0002-7118-3276

Оніщенко Олена Ігорівна,

заслужений діяч науки і техніки України, доктор філософських наук, професор, завідувачка кафедри суспільних наук. Київський національний університет театру, кіно і телебачення імені

I. К. Карпенка-Карого, Київ

Helena Onishchenko,

Honoured Worker of science and technique of Ukraine, Doctor of Philosophical Sciences, Professor, Manager of Social Sciences Department. Kyiv National I. K. Karpenko-Karyi Theatre, Cinema and Television University, Kyiv

\title{
ВІД «ПОСТ» ДО «МЕТА» МОДЕРНІЗМУ: ПРОЦЕС КУЛЬТУРОТВОРЧИХ ПОШУКІВ
}

Анотація. У статті проаналізовано стан європейської гуманістики в динаміці трансформаційних процесів кінця XX - перших десятиліть XXI ст., коли, з одного боку, вичерпаність постмодернізму стає все очевиднішою, а з іншого - окреслення наступного етапу «постмодерністського світобачення» має остаточно невизначені обриси. У даному контексті особливої теоретичної ваги набуває низка проблем, серед яких виокремлено, по-перше - термінологічне «забезпечення» нового етапу постмодернізму, по-друге - з'ясування характеру його «змісту», по-третє - ступінь «розповсюдження» цього змісту в просторі різних видів мистецтва.

Відтворено як специфіку розвитку «постмодернізму» впродовж 1974-2000 рр., так і роль французької гуманістики у «вибудові» нових засад культуротворення, які спиралися б на оновлену манеру філософування, запропоновану в напрацюваннях М.-П.Фуко, Ж. Дерріди, Ж.-Ф.Ліотара.

Ключові слова. Метамодернізм, окреслення змісту, процес культуро-творчих пошуків, види мистецтва, метапроза, історіопластичність, травма, радикальна беззахисність, етико-соліпсичний досвід.

Постановка проблеми та актуальність дослідження. Як відомо, датою народження «постмодернізму» переважна більшість науковців вважає 1974 рік - рік проведення на сторінках американського журналу «Commentary» широкої теоретичної дискусії «Культура і поточний момент». Упродовж цього обговорення сформувалося переконання щодо існування символічної межі, яка відокремила культуротворчі процеси 1900-1970-х рр. від того, що стає значущим у культурному розвитку після 1974 року. Слід визнати, що 70-90-ті pp. ХX століття позначені активним розвитком як філософського, так i естетико-мистецтвознавчого аспектів «постмодернізму», що створив потужний сегмент у просторі європейської гуманістики, помітно вплинувши на мистецькі пошуки у переважній більшості видів мистецтва.

У нашій статті «Метамодернізм: теоретична реальність чи «Фігура Філософії?» (2021) ми детально відтворили як позитивний досвід, так і прорахунки «доби постмодернізму» і констатували факт вичерпаності руху «модернізм-постмодернізм-пост + постмодернізм». Артикулюючи необхідність введення у теоретичний ужиток поняття «метамодернізм», яке здатне виступити означенням нового етапу постмодерністського процесу, ми вважаємо за доцільне здійснити послідовний аналіз цього новоутворення, що, власне, і актуалізує матеріал даної статті.

Аналіз сучасних досліджень $і$ публікацій. Слід зазначити, що в контексті української гу- 
маністики як загальнотеоретичні, так і естетикомистецтвознавчі проблеми «постмодернізму» були об'єктом теоретичного аналізу від початку 70-х рр. $\mathrm{XX}$ століття. Сьогодні можна впевнено говорити про «другу хвилю» праць, яка формує дослідницький простір гуманітарного знання в найширшому значенні цього поняття. Саме серед напрацювань представників «другої хвилі»- Л. Бабушка, Н. Бєлова, О. Геращенко, М. Собуцький, К. Станіславська, С. Холодинська, Г. Чміль - досить виразно окреслені й оцінені експериментальні тенденції творчого процесу тих митців, твори яких відповідають вимогам «постмодерністського» мистецтва.

Mema cmammi. Проаналізувати процес культуротворчих пошуків в умовах завершення «постмодернізму» і формування його нового етапу «метамодернізму», наголосивши на специфіці як «метапрози», так і художніх експериментів тих митців, які атрибутують свою творчість у контексті «метамодерністського» проєкту.

Виклад основного матеріалу. На нашу думку, відпрацьовуючи наріжну проблему цієї статті, слід звернути увагу на публікації європейських науковців, які першими на межі XX-XXI ст. поставили питання про вичерпаність «постмодернізму» в тій його формі, що вважалася провідною наприкінці минулого століття. Підстави для такого висновку давав ортодоксальний «постмодернізм», оскільки низка засад, передусім, чинник «поліметодології», не виправдав теоретичних сподівань, які на нього покладалися. Введення в теоретичний ужиток «поліметодологічної» манери філософування, коли авторитет М.-П. Фукоавтора цієї ідеї - спонукав науковців поєднувати марксизм з ніцшеанством чи психоаналізом, а екзистенціалізм розглядати як складову чи не кожного філософського напряму, себе не виправдало, а в окремих випадках продемонструвало штучність подібних експериментів.

Потенціал «міждисциплінарності» більш виразно виявися в просторі культурології, що «в чистому вигляді» не цікавила засновників «постмодернізму», які опікувалися не теорією чи історією

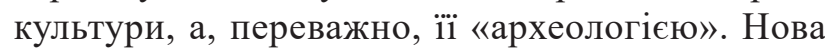
дисципліна - «археологія культури», - на введенні в широкий ужиток якої наполягав М.-П. Фуко, помітно зміщувала наголоси, висуваючи на перші позиції не стільки «теорію культури», скільки їі «глибокі витоки». Враховуючи ж те, що, на думку Фуко, особливу роль в «археології культури» відіграють «феномени», участь таких конструкцій у культуротворчих процесах XXI ст. видається досить проблематичною.
Неоднозначним показало себе і практичне застосування тих художніх чинників, які вважалися наріжними в процесі створення «постмодерністського» мистецтва. Так, «поліжанровість» та «полістилізм» органічно увійшли у простір творчих пошуків як уже відомих митців, так і молодих, для яких експериментальний характер «постмодернізму» сприяв їх самовияву та самореалізації. Водночас, «цитування» та «колажність»- ці чинники обов' язково наявні в переліку наріжних засад творчого процесу «постмодерніста»- беззастережно прийняти неможливо, оскільки їх постійне використання «розчиняє» обриси авторської манери творчості, нівелюючи індивідуальність того чи іншого митця.

Приводом для дискусій стала і двотомна монографія Ж. Дельоза «Кіно» (1985), оскільки кінознавці ставлять під сумнів доречність безпосереднього поєднання філософських ідей А. Бергсона 3 практикою розвитку світового кінематографа. Натомість культурологи, які не поділяють концептуальних засад дельозівського дослідження, особливо акцентують на факті неприйняття засновником інтуїтивізму кінематографа як самостійного виду мистецтва, наголошуючи, що свою позицію філософ висловив не лише відверто, а й категорично.

Усе означене вплинуло на орієнтири відомих культурологів, які- від середини 90-х рр. ХХ ст.і розпочали дискусію щодо вичерпаності «постмодернізму». Слід наголосити, що очевидна штучність поняття «пост+постмодернізм», стимулювала пошуки на теренах осучаснення термінологічного визначення чергового етапу нового культурного процесу, вводячи в ужиток поняття «нео-модерн» (Дж. Деннінг), «офф-модерн» (С. Воум), «ре-модернізм» (В. Чайлдиш). Поступово у цьому «термінологічному розмаїтті» на перші позиції висувається поняття «метамодернізм», якому не лише надають перевагу, а й намагаються зробити суголосними два процеси, а саме: пов'язати з новим теоретико-методологічним підгрунтям, яке формується, так би мовити, на руїнах «постмодернізму», та «підкріпити» новими естетико-художніми засобами.

Своєрідним сигналом до фіксації «кінця постмодернізму» i «запрошення» до накреслення перспектив його подальших культурних модифікацій можна вважати монографію «The Politics of Postmodernism» (2002), автором якої виступила Лінда Хатчеон - відома канадська літературознавиця, представниця школи порівняльного літературознавства. Проголосивши «кінець постмодер- 
нізму», вона, зокрема, підтримала тих фахівців, які вважали за можливе говорити про існування в сучасних умовах «метапрози». Якщо прийняти таку позицію, а для цього $є$ всі реальні підстави, слід констатувати, що на початку XXI ст. з'явився новий - шостий тип прози, що прийшов на зміну реалістичному - натуралістичному - авангардистському - інтелектуальному та постмодерністськомy.

Наразі видається доцільним апелювати до думки відомого англійського письменника Едварда Докса (р. нар. 1972), чиї романи «Калліграф» (2003) та «Допоможи собі сам» (2007) мали значний розголос як серед критиків, так і читачів. В епіцентр уваги природно потрапило і есе «Постмодернізм мертвий», в якому він запропонував вважати датою його смерті 24 вересня 2011 p. Коментуючи позицію Е. Докса, культурологиня Т. Красавченко у статті «Постмодернізм мертвий? Дискусії в англомовній критиці» (2018) наголошує, що саме цього дня у лондонському «Музеї Вікторії та Альберта» була відкрита перша у світі виставка «Постмодернізм - стиль і його повалення: 1970 1990» (Красавченко, 2018, с. 207-209). На думку Т. Красавченко, усе створене за двадцять років показало вичерпаність його естетико-художніх засад і увиразнило процес «руху колом», який виявився очевидним щодо творів 80-90-х рр.

Оскільки в межах цієї статті нас цікавить процес культуротворчих пошуків, який мав місце в інтервалі від «пост» до «мета» модернізму, спробуємо проілюструвати означений інтервал зразками тої мистецької практики, які відбивають творчі пошуки митців XXI ст.

Відтворюючи американсько-європейський літературно-мистецький простір, що формується від початку XXI ст., слід звернути увагу на роман Тоні Моррісон «Улюблена» (1987), що був у переліку тих творів, які принесли письменниці Нобелівську премію з літератури (1993). Окрім означеного роману, афро-американка Тоні Моррісон (1931-2019) - псевдонім Хлої Антоні Воффорд-є авторкою таких непересічних романів, як «Найблакитніші очі» (1970), «Сула» (1973), «Пісня Соломона» (1977), що доволі виразно, на думку критиків, розкрили «розшаровану свідомість», яка «супроводжує життя афро-американців» (Моррісон Т., ЕР).

Слід наголосити, що написання усіх визнаних і високо оцінених фахівцями творів Т. Моррісон збігається $з$ добою «постмодернізму», яку, на американських теренах, зокрема, формувала і ця письменниця. Сьогодні роман «Улюблена» розглядаєть- ся та оцінюється як перший, що був створений, так би мовити, поза «постмодернізмом», відкриваючи шлях «метапрозі».

Сутність та специфіку «метапрози» аналізує і канадський культуролог Джош Тот, який визначив одну з іiі наріжних позицій як «історіопластичну», що означає не відмову від минулого, а його перегляд. Ця ознака «метапрози» послідовно увиразнена у романі «Улюблена»: Сеті - головна героїня твору - рятуючись від рабства в роки Громадянської війни опиняється у штаті Огайо. Саме там вона приймає рішення вбити «Улюблену»-власну доньку, аби врятувати ії від рабства. Дж. Тот фокусує увагу на тому, як Т. Моррісон «знову і знову звертається до головного хвилюючого моменту - жорстокому вбивству Сеті ії доньки, Улюбленої, знову і знову через спіраль нарративних повернень або кидків. Ця подія детально описується неодноразово і щоразу з іншої перспективи» (Тот, 2020, с. 128).

На нашу думку, морально-психологічний «секрет» феномену «історіопластичності» і полягає у можливості одну й ту саму подію побачити у різних аспектах, з різних позицій, прискіпливо розглядаючи деталі. Оскільки письменниця обирає події, що відбувалися в минулому, інші герої роману використовують чинник «часу» та потенціал інтерпретації, що допомагають конструювати «подієвість» на власний розсуд. Таким чином, поступово формується принципово новий естетико-художній подразник: «історія + пластика + персоналізована інтерпретація = історіопластичності».

Порівняно з «постмодернізмом», представники якого у процесі «нашарування» естетикохудожніх подразників або відмовлялися від минулого, або робили його об'єктом «постіронії», «метапроза» дає своїм читачам можливість самостійно «створювати» безліч «минулих», що можуть звільнити їхню обтяжену свідомість та позасвідоме. Т. Моррісон, яка, що вже артикулювалося, є афро-американкою, найобтяжливішим для своєї спільноти, природно, вважає «рабство», звільнення від якого здатне виправдати і вбивство героїнею ії роману власної дитини. Наразі слід завважити, що, експериментуючи та випробовуючи нові творчі прийоми, представники «метапрози», проте, не обходять «моральні провокації», які ставали підгрунтям катарсису - головної мети, що їі впродовж двох тисячоліть прагнули досягти митці у своїх творах.

Ще одним важливим зрізом «метапрози» Дж. Тот визнає оперування феноменом «травма», яка мала місце в минулому. У просторі «сучасного» є можливості «дешифрувати травму» і накрес- 
лити шляхи іiі подолання у «минулому»: означений процес здійснюється завдяки образності літератури та невичерпній кількості художньо-емоційних засобів, якими вона володіє. Подібне «зміщення часу» і письменникам, і культурологам видається реальним:

Ця здатність «оживляти» минуле або утримувати цілісно деякі його аспекти, спираючись на фрагментацію (тобто на здатність концентруватися лише на «частинах») найтіснішим чином пов'язана 3 пластичністю минулого - наріжною і такою, що радикально розширює можливості, - i, як наслідок, з вічною обіцянкою (наснаженою цією пластичністю) того, що травму минулого можна вилікувати або пізнати, нарешті їі реформувавши. (Тот 2020, c. 133-134).

Те, що Т. Моррісон - як представниця «метапрози» - долучає до «побудови» сюжету роману феномен «травми», свідомо концептуалізуючи його, дає підстави говорити про іï психоаналітичні орієнтації, оскільки в теоретичний ужиток поняття «травма народження» в однойменній монографiï, яка вийшла друком у 1924 р., увів послідовник 3. Фрейда, австрійський психоаналітик Отто Ранк (1884-1939). Він, як відомо, останні чотири роки життя працював у США. Це дало підстави, по-перше, вважати О. Ранка американським психоаналітиком, а по-друге - активно «експлуатувати» окремі його ідеї, серед яких значної популярності набула ідея «травми народження», що, на думку О. Ранка, породжує почуття страху. Хоча 3. Фрейд поставився дещо упереджено до відверто фізіологічного «забарвлення» почуттєвого стану «травма - страх», поняття «травма» закріпилося у психоаналітичній теорії.

Згодом, і Фрейд, і неофрейдисти, підсиливши морально-психологічну сутність «травми», дешифрували їі як чинник, що діє, починаючи з дитячих років. При цьому, критично поставившись до тези О. Ранка щодо почуття «страху», яке формується внаслідок «травми народження», 3. Фрейд, котрий свою концепцію страху оприлюднив у праціi «Гальмування, симптом і страх» (1926), був переконаний, що «готовність дитини відчувати страх не виявляється 3 найбільшою силою безпосередньо після ії народження, а виникає протягом іiї психічного розвитку та зберігається певний період дитинства» (Лейбин, Овчаренко, 1998, с. 482).

У романі «Улюблена» Сеті, яка вбиває доньку, «травмована» і переживає «страх», так би мовити, за двох: власні «травма - страх» за вбивство та «травмування страхом», що пережила їі донька перед убивством. Сеті «ховає» спогади у такі гли- бокі надра позасвідомого, з яких їх вкрай важко «підняти» на поверхню психіки: «головна емоційна травма», за висловом Дж. Тота, спонукає героїню стати на шлях ототожнення «пластичності» та «примарності», який стає рушійною силою сюжету моррісонівського роману. Один з аспектів «метапрози» полягає в тому, що дає змогу «матеріалізувати», наприклад, «примарність», якою в романі «Улюблена» виявляється вбита Сетою донька, а «матеріалізація примарності», що трансформується у постать «привида», відбувається за «допомогою» пам'яті.

На нашу думку, подібний «рух» роману, не стільки актуалізує пам'ять, яку у «метапрозі» оцінюють як «окам'янілу» структуру, скільки одразу ж наштовхує іiі (пам'ять - O.O.) на привид «батька Гамлета» і бажання звинуватити Т. Моррісон у «постмодерністському цитуванні» класики. Не вдаючись до розгорнутих розмислів 3 цього приводу, ми, наразі, лише зафіксуємо властиві й «метапрозі», найпримітивніші виходи зі складних творчо-пошукових ситуацій, в які можуть завести експерименти на літературних теренах.

Слід наголосити. що, по-перше, у низці своїх тверджень Дж. Тот солідаризується з Л. Хатчеон, яка проголосила завершення доби «постмодернізму». Дж. Тот, з одного боку, поділяє іiї позицію, а 3 іншого, переключаючи увагу на «метамодернізм» загалом і його модифікацію у вигляді «метапрози» зокрема, досить ретельно «збирає» зразки саме «метамодерністського» мистецтва. Так, у його полі опиняються не лише такі романи, як «Дім листя» (2000) Данілевські та «Яйця у цукровій глазурі» (2012) Лейнера, а й низка фільмів, зокрема - «Безславні виродки» (2009) Тарантіно, «Вовк з Уолл-Стріт» (2013) Скорсезе (Тот, 2020, c. 150).

Дещо інші наголоси щодо «метапрози» робить Ніколін Тіммер, наукові розвідки якої достатньо популярні на америко-нідерладських теренах. Ï̈̈ дослідження «Do You Feel It Too? The Post-Postmodern Syndrome in American Fiction at the Turn of the Millennium» (2010) не лише мало широкий розголос серед культурологів, а й дало змогу скорегувати окремі позиції, які мають місце в сучасній гуманістиці і стосовно термінологічних розходжень, і щодо сутнісних ознак «метапрози».

3 формального боку, Н. Тіммер відносить себе до «пост+ постмодерністів», не заперечуючи, водночас, і проти поняття «метамодернізм», послідовне відстоювання якого вона пов'язує з іменем відомого нідерландського культуролога Робіна ван дер Аккера. Визнаючи наявність термінологічних 
розходжень у сучасній європейській гуманістиці щодо означення процесів, які відбуваються у просторі культуротворення, вона врешті-решт ототожнює поняття «пост+постмодернізм» та «метамодернізм». Окрім цього, Н. Тіммер висловлює, хоча і дискусійну, але досить несподівану думку: незалежно від того, яким терміном буде позначений сучасний стан культури, він є відповіддю «на сувору дієту постструктуралістської теорії» (Тиммер, 2020, c. 258).

Критичне ставлення Н. Тіммер до постструктуралістської теорії, на потенціал якої, переважно, і спирався «постмодернізм» на початковому етапі свого розвитку, обумовлений його нездатністю «вимірювати людяність». Саме це, радше метафоричне, ніж теоретичне визначення, спровокувало бажання теоретика «придивитися» до нових «віянь у сучасній теорії, літературі та культурі» (Тиммер, 2020, c. 258).

Його реалізація здійснилася тоді, коли в поле зору Тіммер потрапила творчість американського письменника Д.-Ф. Воллеса, враження від якої Тіммер описує низкою іменників та прикметників: «... «почуття чогось-то», «щось невідкладне і людське», «безіменне, обтічне, невідкладне, міжлюдська схожість», «щось, що вкрай важко визначити»... » (Тиммер, 2020, с. 257-258) Слід наголосити, що подібну характеристику творчої манери письменника не можна назвати «чистим літературознавством», проте інтерес до конкретної персоналії виникає одразу ж.

Девід Фостер Воллес (1962-2008) - американський письменник, есеїст, один з ідеологів руху «Нова щирість», спадщину котрого фахівці оцінюють як видатне явище американської літератури кінця XX - початку XXI ст. Майбутній письменник з'явився на світ у професорській родині: батько - професор філософії, мати - професорлінгвіст. Батьки Воллеса зорієнтовували його на різнобічні «професійні шляхи», спираючись на ті можливості, які відкривав Армхетський коледж: дипломи з модальної логіки, англійської мови та літератури. У 1987 р. він отримав ступінь магістра 3 «витончених мистецтв» за вузькою спеціалізацією- «словесність».

Пізніше, у листі до Джонатана Ерла Франзена (р. нар. 1959), який сьогодні - завдяки романам «Виправлення» (2001) та «Свобода» (2010) - визнається літературознавцями найвидатнішим американським письменником початку XXI ст., Воллес назвав 1983 рік - роком «відкриття інтересу до письменництва, яке має базуватися на єдності морального, естетичного та екзистенційного під- ходів». Тисячесторінковий роман Д.-Ф. Воллеса «Безкінечний жарт» (1996) отримав найвищі оцінки з боку професійної критики. Пізніше з'являються такі твори, як «Короткі інтерв’ю з покидьками», що був екранізований Джоном Красиньські (2009), та « Це вода» (2005). Ми акцентуємо на творах, які побачили світ за життя письменника, який, страждаючи на важкі депресії, у 2008 р. вкоротив собі віку. Вже по його смерті друком виходить роман «Блідий король» (2011) і низка есе та оповідань (Уоллес, ЭР).

На нашу думку, аналіз творчості Д.-Ф. Воллеса як прихильника естетико-художніх вимог «метапрози», запропонований Н. Тіммер, доцільно співвіднести із засадами руху «Нова щирість», до якого належав письменник. Як відомо, на американських теренах «Нова щирість» почала формуватися після Другої світової війни, коли митці - цей рух підтримували не лише літератори, а й представники кінематографа та музики, - вважали за необхідне створювати мистецтво «на засадах людяності». Маючи певні напрацювання, «Нова щирість» здобула справжню популярність за часів «постмодернізму», що іiї представники високо цінували «постіронію» як специфічний засіб естетикохудожньої виразності і як моральнісну константу «постмодерністських» творів.

Представники руху «Нова щирість» категорично засуджували подібну орієнтацію «постмодернізму» як таку, що, з одного боку, руйнує людяність, а з іншого-знищує серйозне ставлення спільноти до смисложиттєвих проблем сучасності. Для «Нової щирості» оцінка «постмодернізму» як аморального феномену вважається не лише допустимою, а й об'єктивною (Движение... ЭР).

Актуалізація ідей «Нової щирості», розпочата у 80-ті роки, підтримується Д.-Ф. Воллесом в есе «E Unibus Pluram Television and Literature of USA» (1993), на сторінках якого письменник закликає митців, незалежно від виду мистецтва, в якому вони працюють, відродити «лірико-сповідальну манеру творчості». Такий заклик не стільки спрямовує «мистецький погляд» у майбутнє, скільки заохочує по-новому поглянути на минуле. Саме тому Н. Тіммер, перелічуючи «іменники і прикметники», об'єкт позначення яких нею не визначається, намагається «намацати» ті специфічні ознаки, що притаманні романам Воллеса і вирізняють їх серед інших зразків «метапрози».

Н. Тіммер, увиразнюючи найбільш типові риси «метапрози» Д.-Ф. Воллеса, наголошує на іï морально-етичному аспекті, витоки якого сягають напрацювань видатного австро-англійського філо- 
софа, логіка, представника аналітичної філософії Людвіга Вітгенштейна (188-1951), який у своїй «Лекції про етику» (1929) найбільш цінував те, «про що слід умовчувати». Н. Тіммер наголошує, що Воллеса зацікавило саме те, що Л. Вітгенштейн хотів залишити поза увагою широкого кола читачів. На їі думку, маються на увазі виокремлені філософом «три види досвіду». При цьому Вітгенштейн акцентував, що означений досвід має «чисто» особистісний характер.

В інтерпретації Н. Тіммер позиція Л. Вітгенштейна виглядає так:

Досвід par excellence для нього має місце, коли «я дивуюсь існуванню світу»; другий досвід спирається на «переживання абсолютної безпеки», а третій, що пропонується не так помітно,-це досвід «почуття провини». Ці три види досвіду і являють собою те, що Вітгенштейн назває етичним досвідом. (Тиммер, 2020, с. 259).

Н. Тіммер наголошує, що, на думку австроанглійського філософа, сам факт «формулювання цих трьох видів досвіду відчувається як некоректне використання мови», чітко розділяючи при цьому функціональні завдання мови та моральнісні чинники, оскільки «етичні види досвіду, які він (Л. Вітгенштейн - O.O.) намагається виразити, мають не відносну, а внутрішню, абсолютну цінність. Ось чому Вітгенштейн називає їх або «надприродним», або «містичним»; вони вислизають із світу фактів, а це означає, що вони вислизають і від мови» (Тиммер, 2020, с. 259-260).

Нормативи статті не дають нам можливості повністю відтворити аргументи, завдяки яким Л. Вітгенштейн доводить як теоретичне значення, так і життєво-прагматичний сенс трьох «етичних досвідів». Адже для нашої розвідки вкрай важливо показати, який «пластичний міст» намагається «побудувати» Д.-Ф. Воллес між настановами Л. Вітгенштейна і певними засадами свого світобачення. При цьому Н. Тіммер стверджує, що ті романи, в яких Д.-Ф. Воллес спробував, «вийти за межі мови» і сприяли появі деяких обрисів «нової етики»:

Саме в цьому жесті, спрямованому на те, аби за допомогою мови вийти за межі мови, виходить на перший план сусідство 3 «чимось невідкладним», до якого ми наближаємося. Цим «чимось» може бути близькість як така, близькість до іншого, яка наявна у всіх світах соліпсичного досвіду, який Уоллес описує з такою енергією й стилістичною терпимістю. (Тиммер, 2020, с. 261).

Залишивши на маргінесах нашої свідомості вираз «стилістична терпимість», що його не може пояснити ані Н. Тіммер, ані ми, зосередимося на феномені «соліпсизм», похідним від якого є воллівський «соліпсичний досвід». Оперуючи поняттям «соліпсизм - від латин. solus - самотній та ipse сам», яке входить у філософський ужиток від часів життя Горгія з Леонтіні (483-375 до н.е.), який стверджував, що нічого не існує, а якщо існує, то це не можна довести (Солипсизм, ЭР), Воллес сконцентрував увагу на, так би мовити, його серцевині, а саме - сприйманні власної індивідуальної свідомості як адекватного замінника об'єктивної реальності.

На думку Н. Тіммер, проблему соліпсизму слід розглядати як «ключ до всієї творчості Воллеса», що стало очевидним вже після одного з його перших творів - «На захід курс імперії бере свій шлях», який сьогодні скорочено називають «На захід», де наріжною постаттю розповіді виступає сам Воллес в образі професора Емброуза, «невпевнене "Я” котрого, - як зауважує Н. Тіммер, потребує постійного самоствердження»: «Таким чином. у метапрозі вони (персонажі твору $-O . O$.) можуть знайти штучний, стверджувальний аналог самостворення, яким їм доводиться займатися повсякденно» (Тиммер, 2020, с. 266).

Слід враховувати, що ключовим словом у тезі Н. Тіммер $є$ «самостворення», яке - це переконливо показує Д.-Ф. Воллес-є досить складним процесом, від якого і власне Воллес, і герої його творів втомилися, виявившись ще більш самотніми, ніж вони це собі уявляли. Самотність виступає кінцевою зупинкою як смисложиттєвих пошуків людини, так і її життя.

«Метапроза» поки що має не дуже тривалу історію наявності у світовому літературному просторі, пройшовши шлях від «пост» до «мета» модернізму. Однак активний розвиток «метамодернізму» в різних видах мистецтва, який спостерігається сьогодні, вноситиме корективи і в процес розширення естетико-художніх засобів виразності «метапрози».

Висновки. Матеріал, розглянутий у статті, підтверджує факт досить активної дослідницької роботи, яка останні два десятиліття ведеться на теренах «метамодернізму». Показано, що, окрім відпрацювання поняття «мета- модернізм», науковці значну увагу приділяють «метапрозі», теоретичні засади якої сформовані американськими письменниками Т. Моррісон, Д.-Ф. Воллесом та Дж. Франзеном. Саме вони - першими у контексті «метамодернізму» - актуалізували рух «Нова щирість» та почали розробляти на підгрунті його ідеології нові чинники естетико-художньої виразності, зокрема, «історіопластичність», «травму як 
художньо-спонукальний чинник», «радикальну беззахисність», «етико-соліпсичний досвід».

\section{Джерела та література}

Красавченко, Т.Н. (2018). Постмодернизм мёртв? Дискуссии в англоязычной критике (Обзор): статья. Зарубежная литература. Серия 7 - литературоведение. Москва. Вып. № 3. C. 207-217.

Моррисон, Тони [ЭР]. Режим доступа: https // www.wonderline. com $>224071$ - toni - morrison

Тот Дж. (2020). «Возлюбленная» Тони Моррисон и становление историопластичной метапрозы: статья / Дж.Tom // Р. ван дер Аккер. Метамодернизм. Историчность. Аффект и Глубина после постмодернизма ; [перев. с англ. В.М. Липки, вступ. ст. А.В. Павлова]. Москва: РИПОЛ-классик. С. 122-150.

Лейбин, В.М., Овчаренко, В.И. (1998). Травма рождения (греч. тrauma - повреждение организма). Психоанализ. Энииклопедия / Сост., науч. ред. П.С. Гуревич. - Москва: Олимп. ООО «Фирма «Издательство АСТ». С. 480-482.

Тиммер, Н. (2020). Радикальная Беззащитность: новое ощущение собственного «Я» в творчестве Дэвида Фостера Уоллеса: статья / Н.Тиммер // Р. Ван дер Аккер. Метамодернизм. Историчность. Аффект и Глубина после постмодернизма; [перев. с англ. В.М. Липки, вступ. ст. А.В. Павлова]. Москва: РИПОЛ-классик. С. 257-284 (Фигуры Философии).

Уоллес Дэвид Фостер. [ЭР]. Режим доступа: https. // www. livelib. ru $>301650$ - devid - foster - uolles

Движение «Новая искренность». [Эл.Р]. Режим доступа: https // hsepress. ru $>$ articles $>$ novaya - iskrennost

Солипсизм [ЭР]. Режим доступа: http. // www. cablook. com

$>$ mixlook $>$ sovsem - odin - radi

\section{References}

Krasavchenko, T.N. (2018). Postmodernizm mYortv? Diskussii $\mathrm{v}$ angloyazyichnoy kritike (Obzor) [Is post-modernism dead? Discussions in to English-language criticism] : statya. Zarubezhnaya literatura. Seriya 7 - literaturovedenie. Moskva. Vyip. № 3. S. 207-217.

Morrison, Toni. [ER]. Rezhim dostupa: https // www.wonderline. com $>224071$ - toni - morrison

Tot, Dzh. (2020). «Vozlyublennaya» Toni Morrison i stanovlenie istorioplas-tichnoy metaprozyi [«Beloved» of Тони is Morrison and becoming historioplastic metafiction] : statya / Dzh.Tot // R. van der Akker. Metamodernizm. Istorichnost. Affekt i Glubina posle postmodernizma; [perev. s angl. V.M. Lipki, vstup. st. A.V. Pavlova]. Moskva: RIPOL-klassik. S. 122-150.

Leybin, V.M., Ovcharenko, V.I. (1998). Travma rozhdeniya (grech. trauma - povrezhdenie organizma) [Trauma of birth]. Psihoanaliz. Entsiklopediya / Sost., nauch. red. P.S. Gurevich. - Moskva: Olimp. OOO «Firma «Izdatelstvo AST». S. 480482 .

Timmer, N. (2020). Radikalnaya Bezzaschitnost: novoe oschuschenie Sobstvennogo «Ya» v tvorchestve Devida Fostera Uollesa [Radical Defencelessness: new feeling own «I» in work of David Foster Uolles]: statya / N.Timmer // R. Van der Akker. Metamodernizm. Istorichnost. Affekt $i$ Glubina posle postmodernizma ; [perev. s angl. V.M. Lipki, vstup. st. A.V. Pavlova]. Moskva: RIPOL-klassik. S. 257-284 (Figuryi Filosofii).

Uolles Devid Foster. [ER]. Rezhim dostupa: https. // www. livelib. $\mathrm{ru}>301650$ - devid - foster - uollesDvizhenie «Novaya iskrennost». [ER]. Rezhim dostupa: https // hsepress. ru > articles $>$ novaya - iskrennost

Solipsizm [ER]. Rezhim dostupa: http. // www. sablook. com > mixlook $>$ sovsem - odin - radi

\section{Helena Onishchenko}

\section{From post- to metamodernism: process cultural research}

Abstract. The article analyzes the state of European humanities in the dynamics of transformation processes of the late XX - first decades of the XXI century, when, on the one hand, the exhaustion of postmodernism becomes more obvious, and on the other - outlining the next stage of «postmodern worldview» has definitively vague outlines. In this context, a number of problems acquire special theoretical importance, among which are singled out, first - the terminological «provision» of a new stage of postmodernism, secondly - clarifying the nature of its «content», and thirdly - the degree of «spread» of this content in space of different arts.

Both the specifics of the development of «postmodernism» during 1974-2000 and the role of French humanities in «building» new principles of cultural creation, which would be based on the renewed manner of philosophizing proposed in the works of M. Foucault, J. Derrida, J.-F.Liotar.

Key words: Metamodernism, delineation of the content, the process of cultural and creative research, arts, metaprose, historioplasticity, trauma, radical insecurity, ethical-solipsic experience. 